Ewa JURGA

Uniwersytet im. Adama Mickiewicza, Poznań

\title{
Ograniczenia niezależności w układzie dziennikarz - redaktor naczelny - wydawca (właściciel) w prasie lokalnej
}

Pozycja ekonomiczna pisma determinuje wolność i niezależność dziennikarską. Potwierdzeniem tej tezy są badania nad prasą lokalną powiatów gostyńskiego, górowskiego, kościańskiego, leszczyńskiego, rawickiego $\mathrm{i}$ wschowskiego przeprowadzone $\mathrm{w}$ latach $1999-2003^{1}$. W praktyce dziennikarskiej szczególnie lokalnych pism prywatnych można zauważyć, iż kwestie finansowe mają zwykle pierwszeństwo nad etyką dziennikarską. Działania takie przysłaniają fakt, podkreślania przez redakcje niekomercyjnego charakteru prasy. Większość pism zamieszcza w podtytule informację, że są niezależne i opiniotwórcze. W tym ostatnim kontekście zapewne chodzi o wpływanie prasy na stan świadomościowy społeczeństwa, a to jak wiadomo mija się z celami komercyjnymi. W przeciwieństwie do pism prywatnych tytuły samorządowe bądź subsydiowane przez organy samorządu terytorialnego nie są nastawione na zysk. Dziennikarze tego typu pism często pracują społecznie, nie pobierając za pracę redakcyjną wynagrodzenia. Redakcjom takim zależy na akceptacji przez społeczeństwo instytucji, które reprezentują.

Prasę lokalną, ze względu na kryterium - wydawca, można podzielić na prywatną, samorządową i ukazującą się pod patronatem instytucji kulturalnych, często stowarzyszeń. Ten trzeci wyróżnik, podkreślany w literaturze przedmiotu jest nieczytelny. Zdarza się bowiem, iż takie pisma są subsydiowane przez instytucje samorządowe. Co z góry zakłada ograniczenia swobody ich działalności. Zatem nie wypada gazetom, a w

1 E. Jurga, Prasa lokalna $w$ powiatach - gostyńskim, górowskim, rawickim $i$ wschowskim, w: Prasa dawna i wspótczesna, pod red. B. Kosmanowej, część czwarta, Poznań 2003, s. 129-141; E. Jurga, Prasa lokalna Ziemi Kościańskiej, w: Prasa dawna i współczesna, pod red. B. Kosmanowej, część druga, Poznań 2001, s. 7-23; E. Jurga, Prasa lokalna w Lesznie, w: Z dziejów prasy wielkopolskiej XIX-XX wieku, pod red. J. Załubskiego, t. IV, Poznań 2003, s. 111-131. 
przypadku pism samorządowych jest niedopuszczalne - pisać źle o miejscowej władzy.

Lokalna prasa prywatna funkcjonowała na rynku w formie spółek prawa handlowego (np. „Panorama Leszczyńska” od 1998 r., sp. z o.o.), spółdzielni (np. „Panorama Leszczyńska” w latach 1992-1998) i podmiotów gospodarczych - przedsiębiorców (,Słowo Ziemi Wschowskiej”). W ogólnopolskich tytułach widoczny jest proces oddzielania właściciela i wydawcy od dziennikarzy najemnych. W wysokonakładowej prasie lokalnej częstym zjawiskiem jest wykup przez dziennikarzy udziałów w firmie wydawniczej. W praktyce zauważa się, iż osoba mająca najwięcej udziałów, staje się prezesem firmy i redaktorem naczelnym pisma, wydawanego przez tę firmę („Panorama Leszczyńska”, „ABC. Dziennik Informacyjny").

W sytuacji, gdy właściciel i wydawca jest pracodawcą dziennikarza (zatrudnienie w oparciu o stosunek pracy), skutkuje to konsekwencjami zawodowymi wynikającymi z Kodeksu pracy. Podległość służbowa dziennikarza i określany przez bezpośredniego przełożonego (często przez redaktora naczelnego, który de facto jest zarówno właścicielem, jak i wydawcą) zakres obowiązków staje się tamą na niezależność, rzetelność i obiektywizm w działalności dziennikarskiej. W tym kontekście istotna jest struktura organizacyjna redakcji, w której dziennikarz jest zatrudniony. Determinuje ona funkcjonowanie dziennikarzy będących na etacie. Nieco inaczej kształtuje się sytuacja dziennikarzy - współpracowników, ci bowiem nie są związani z redakcją stosunkiem pracy. Pomimo tego, jak wskazuje praktyka, ich sytuacja wcale nie jest komfortowa. Ze strony redakcji nie posiadają zabezpieczenia w postaci chociażby ochrony socjalnej, choć to dla większości z nich nie jest ważne, bo zwykle są zatrudnieni $\mathrm{w}$ pełnym wymiarze pracy $\mathrm{w}$ innych instytucjach. Problem stanowi zwłaszcza uwikłanie współpracowników redakcji w politykę lokalną. Należy pamiętać, że w przypadku współpracowników w prasie lokalnej nie mówimy o tzw. zwykłych ludziach. Tutaj dziennikarzami są osoby pełniące poważane funkcje w środowisku lokalnym. Prasę lokalną tworzą zazwyczaj pracownicy urzędów, miejscowych ośrodków kulturalnych, bibliotek i innych instytucji. W tej mierze wyjątek stanowią pisma o stosunkowo dużym nakładzie i rozbudowanym kolportażu (np. „ABC. Dziennik Informacyjny”, „Panorama Leszczyńska” czy „Wiadomości Kościańskie"). Współpracownikami zaś są najczęściej urzędnicy samorządowi, osoby prowadzące własną działalność gospodarczą, historycy, regionaliści, nauczyciele oraz młodzież ucząca się i studiująca. 
Zatem ograniczenia wolności można rozpatrywać na trzech poziomach - ekonomicznym, organizacyjnym i politycznym ${ }^{2}$.

\section{Poziom ekonomiczny}

Typowym zjawiskiem rynku prasowego po 1989 roku jest komercjalizacja, czyli rozwój prywatnych wydawnictw i prywatyzacja dotychczasowych monopolistów. W charakterze właściciela oprócz dotychczasowego Skarbu Państwa (np. „Wiadomości Kościańskie” w latach 1986-1991) pojawiają się coraz częściej: inwestor zagraniczny (np. porozumienie „Gazety Kościańskiej” z „Głosem Wielkopolskim”, udziałowcami tego ostatniego w listopadzie 2002 r. byli m.in. Centrex Press Holandia i od 2003 r. niemiecki koncern Polskapresse ${ }^{3}$ ), prywatne podmioty gospodarcze (np. „Zmiany Nadobrzańskie” w 1991 r.) i osoby fizyczne inwestujące w rynek prasowy (np. „Forum Kobylińskie”). Inwestycje te są powiązane $\mathrm{z}$ działalnością reklamową. A zatem zaciera się różnica pomiędzy pojmowaniem misji dziennikarskiej jako rzetelnego i obiektywnego informowania a dziennikarską akwizycją. W ten sposób występuje przyzwolenie wydawców na uprawianie przez dziennikarzy kryptoreklamy.

Wydawca kontroluje prasę pod kątem przychodów i realizacji media planów (budżet, działalność PR). Dlatego też na bieżąco kontroluje materiały mające ukazać się w prasie i same już publikacje. Dostrzegalna jest też jego rola w określaniu, na której stronie i w którym miejscu mają ukazywać się określone (w sensie preferowanego przez wydawcę) reklamy. Decyduje też o kierunku kolportażu.

Sukcesy komercyjnych tytułów lokalnych przyczyniają się do zmian na rynku prasy. Tworzą się nowe inicjatywy prasowe, które niosą za sobą - nowe przekształcenia własnościowe (prywatyzacje), podnoszenie merytorycznego i graficznego poziomu tytułów. Komercjalizacja napędza lokalną gospodarkę, to przede wszystkim nowe miejsca pracy i przyciaganie możliwością reklam nowych inwestorów. Niestety należy stwierdzić, że działalność prasy jako przedsięwzięcia zorientowanego na rynek, opiera

2 Problem ten autorka omawia w oparciu o wyniki samodzielnych badań, zgromadzonych za pomocą wywiadu kwestionariuszowego dotyczącego działalności redakcji prasy lokalnej powiatów - gostyńskiego, górowskiego, kościańskiego, leszczyńskiego, rawickiego i wschowskiego, przeprowadzonego w latach 1999-2003.

3 J. Załubski, Dlaczego polscy wydawcy opuścili „Glos Wielkopolski”?, w: Zdziejów prasy wielkopolskiej, pod red. J. Załubskiego, t. V, Poznań 2003, s. 187. 
się na zasadach, które pomijają m.in. kwestie pluralizmu pisma, treści programowych, zdolności do wyrażania opinii funkcjonujących w społeczeństwie i niezależności mediów. A zatem w prasie zamieszczana jest stosunkowo duża ilość reklam i rozrywki w postaci krzyżówek (tzw. ciągówki lokalne, w których zawsze jedno z pytań brzmi - przy jakiej ulicy znajduje się sklep z towarami X), które prowadzą do kryptoreklamy.

\section{Poziom organizacyjny}

Typowa lokalna redakcja liczy do pięciu osób. Charakteryzuje się brakiem specyfikacji zawodowej, tzn. dziennikarze zajmują się wszystkimi elementami procesu redakcyjno-wydawniczego (od redagowania poprzez składanie gazety po kolportaż). Natomiast zdarzają się wyjątki. Tutaj zdecydowanie wiodą prym gazety prywatne (np. „Nowa Gazeta Gostyńska”). W nich najczęściej wyróżnia się cztery działy spełniające wyspecjalizowane funkcje i zadania: redakcyjny (wydawniczy), techniczny (produkcyjny), reklamowy (w tym promocji i marketingu) i kolportażowy (dystrybucji i sprzedaży). Na tym tle dochodzi do konfliktu interesów między wydawcą (właścicielem), redaktorem naczelnym i dziennikarzami.

Wydawca (właściciel) będący podmiotem stojącym najwyżej w hierarchii, odpowiada za stronę ekonomiczną i wydawniczą przedsięwzięcia. W zakresie jego zadań należy - angażowanie środków finansowych, dbałość o wzrost reklamodawców, zapewnienie dobrych stosunków z lokalną elitą polityczną, określanie ogólnej linii programowej pisma i rozwój nakładu. To wszystko ma prowadzić do sukcesu komercyjnego pisma. Oczywiście, niektóre z tych zadań, szczególnie kwestie pozaekonomiczne są cedowane na redaktora naczelnego pisma. Chyba że, wydawca i redaktor naczelny to ta sama osoba. W istocie jednak redaktor naczelny realizuje wizję wydawcy. To on sprawuje nadzór nad m.in. procesem wydawania, planowania tematów, informowania działu reklamy o zamierzeniach wydawcy, prowadzi redakcyjną politykę kadrową i reprezentuje pismo na zewnątrz. W redakcji pojawia się też funkcja sekretarza redakcji, który reaguje na bieżące sprawy dotyczące pisma, konsultując się z redaktorem naczelnym, kierownikami działów i pracownikami technicznymi (np. graficy komputerowi). Czasami występują też w redakcji członkowie kolegium redakcyjnego i zauważalny jest podział na specjalizacje wewnątrzredakcyjne. Można wyróżnić - publicystów, dziennikarzy, fotoreporterów, grafików i adiustatorów. 
Sytuacja dziennikarza w strukturze organizacyjnej jest determinowana przez podział kompetencji (władzy), profil pisma i sposób realizacji linii programowej. Najważniejszą częścią tej struktury jest układ kapitałowy wydawcy, od którego uzależnione są relacje z redaktorem naczelnym i dziennikarzami jemu kompetencyjnie podległymi, a w niektórych tytułach lokalnych też prezesem zarządu i jego działami nieredakcyjnymi. Jednakże Prawo prasowe powierza redaktorowi naczelnemu prowadzenie spraw redakcji ,uprawnienia do decydowania o całokształcie funkcjonowania redakcji" (art. 7; ust. 2 pkt 7 p.p.). A zatem dziennikarz jest całkowicie uzależniony od polityki kadrowej wydawcy, którą w praktyce realizuje redaktor naczelny. Ponadto redaktor naczelny sprawuje nadzór merytoryczny i ocenia pracę dziennikarzy. O zatrudnieniu zwykle decyduje redaktor naczelny $\mathrm{w}$ porozumieniu $\mathrm{z}$ wydawca. Ten ostatni, prowadząc politykę ekonomiczną pisma, ma w tej kwestii często decydujące zdanie. Zdarzały się przypadki, że to z jego inicjatywy dochodziło do redukcji etatów, co zmniejszało koszty osobowe, a więc poprawiało wynik finansowy przedsięwzięcia wydawniczego.

W prasie lokalnej w przeciwieństwie do prasy ogólnopolskiej rzadko w praktyce działają obok siebie - redaktor naczelny i prezes zarządu (zarząd reprezentuje interesy wydawcy). Niemalże we wszystkich tytułach lokalnych dwa najważniejsze zadania kierownicze, czyli prowadzenie finansów i całokształt dziennikarski pisma powierzane są jednej i tej samej osobie - podmiotowi reprezentującemu wydawcę - zarządowi czy też jego prezesowi pełniącemu jednocześnie funkcję redaktora naczelnego.

Sposób zarządzania zależy od formy własności tytułu, z niej biorą się uprawnienia do kierowania zespołami osób przyczyniających się do powstania pisma. W przypadku prasy samorządowej zarządzanie odbywa się za pomocą redaktora naczelnego bądź redaktora odpowiedzialnego wybranego przez organy samorządowe do tego uprawnione (rada, zarząd) w drodze uchwały. Akt ten zatwierdzał proponowanego kandydata na funkcję redaktora naczelnego (odpowiedzialnego) lub zawierał decyzję o zleceniu prowadzenia redakcji i wydawnictwa instytucji samorządu terytorialnego. W tym ostatnim określano zazwyczaj tylko zasady finansowania pisma, pomijając kwestie organizacyjne redakcji, co sprzyjało pozornie jej swobodzie działania. Zatem kierowanie redakcją spoczywało w rękach zespołu redakcyjnego (wybranego przez redaktora naczelnego), w którym pozycję najważniejszą zajmował redaktor naczelny wybrany w drodze nominacji przez właściciela pisma. Jednak wydawca - samorząd terytorialny, najczęściej zlecał prowadzenie redakcji pisma określonemu 
zespołowi osób. Uchwała taka zawierała liczebny i personalny skład redakcji, co ograniczało autonomię pisma.

Wydawcy prywatni (spółki z o.o., sp. komandytowe, osoby fizyczne prowadzące działalność gospodarczą) dokonywali również nominacji redaktora naczelnego, którym w wielu wypadkach był właściciel wydawnictwa. W sytuacji, gdy właścicielem był podmiot typu korporacyjnego (w formie spółki) wyboru redaktora naczelnego dokonywały uprawnione do tego organy (zarządy spółki, zgromadzenie wspólników lub właścicieli). Na tym spotkaniu czasami sporządzano regulamin pracy redakcji, określano strukturę redakcji i wyznaczano zakres zadań poszczególnych pracowników.

Interesująca jest więc organizacja prasy samorządowej i instytucji kulturalnych, którą należy rozpatrywać raczej w kontekście związków politycznych. Jak już wspomniano wcześniej, pisma te mają niski poziom komercyjny. Na ich łamach niezwykle rzadko pojawiają się reklamy. Tytuły są subsydiowane przez instytucje samorządowe. Stąd układ wydawca - redaktor naczelny i dziennikarze, charakteryzuje się relacjami politycznymi, a niezwykle rzadko ekonomicznymi.

\section{Poziom polityczny}

Redaktorzy dostrzegają fakt, iż aby gazeta mogła wypracować sobie zaufanie odbiorców, to musi uwolnić się od więzów politycznych. W środowisku lokalnym zjawisko odpolitycznienia mediów występuje rzadko, choć redaktorzy i dziennikarze chętnie na swoich łamach podkreślają niezależność prasy. Szczególnie wskazują na to gazety prywatne, de facto tak samo uwikłane w lokalną politykę, jak prasa samorządowa i wydawana pod auspicjami różnych towarzystw kulturalnych. Dowodem na to, jest zawartość treści. Tytuły prywatne zainteresowane są wszystkimi negatywnymi zjawiskami zaistniałymi w środowisku lokalnym. Polemizują w mniej znaczących sprawach odnośnie władz samorządowych, natomiast w istotnych kwestiach próbują zachować neutralne stanowisko, często też tłumacząc decyzje władz lokalnych. Zatem owa niezależność jest tylko stwierdzeniem - wyróżnikiem określonej prasy lokalnej na tle innych tytułów. Upolitycznienie prasy jest najwyraźniej dostrzegalne podczas kampanii politycznych, zwłaszcza samorządowych. Świadczą o tym sytuacje, kiedy prywatna prasa lokalna wysuwa i popiera swoich niezależnych kandydatów (ugrupowanie polityczne) do uzyskania mandatu radne- 
go. Analizując w tym okresie zawartość treści tytułów, można zauważyć uprzywilejowane osoby (ugrupowania polityczne) będące głównymi podmiotami w takich formach wypowiedzi jak - informacje, artykuły publicystyczne czy reklamy polityczne. Osoby uprzywilejowane są umieszczane na preferencyjnych warunkach. Po wyborach okazuje się, o ile uzyskały one mandat radnego, to współpracują z danym pismem. Stają się ekspertami z zakresu polityki lokalnej. Ich rola nie ogranicza się do informowania, stają się bowiem tzw. nieetatowymi dziennikarzami, czyli współpracownikami. W wielu przypadkach nie podpisują się nazwiskiem i imieniem tylko inicjałami lub pseudonimem.

W prasie samorządowej i ukazującej się pod szyldem różnych towarzystw kulturalnych, zauważany jest związek dziennikarzy z polityką lokalną. Są kolumny, w których burmistrzowie i radni wyrażają swoje stanowisko odnośnie spraw samorządowych. Pracownicy tych czasopism wykonują prace dziennikarzy społecznie, ponieważ prowadzenie pisma traktują jako zadanie zlecone przez zarządy gmin (powiatów) czy instytucji kulturalnych, a uposażenia otrzymują w związku z zatrudnieniem w placówkach samorządowych. Redaktorzy naczelni realizują politykę instytucji samorządowych - wydawców. Dziennikarze merytorycznie podlegają redaktorowi, ale politycznie jak i kompetencyjnie - tak jak redaktor, są rozliczani przez wydawcę.

W literaturze przedmiotu przedstawiane są trzy czyste modele statusu redaktora naczelnego, co wskazuje na zależności w wewnętrznej strukturze organizacyjnej, a to ma wpływ na podstawę ekonomiczną i polityczną pisma $^{4}$. W pierwszym modelu redaktor naczelny jest członkiem zarządu. $\mathrm{W}$ tym ujęciu jest on jedynym przedstawicielem kierownictwa pisma i jednocześnie członkiem zarządu. Zatem jest szefem pionu dziennikarskiego i osobą odpowiedzialną za sprzedaż i stronę techniczną pisma. Wobec tego sprawuje on zasadniczą władzę nad finansami swojej firmy. I w związku z tym to on rozstrzyga konflikty pracownicze, planuje budżet firmy i wyznacza jej dalszą strategię.

W drugim modelu - redaktor naczelny posiada pozycję autonomiczną. Aby firma dobrze funkcjonowała zadania prezesa i redaktora naczelnego muszą być jasno sprecyzowane, szczególnie w warstwie odpowiedzialności redaktora naczelnego, prezesa i zarządu czy wydawcy. Generalnie re-

4 L. Szot, Wolność dziennikarzy w polskim systemie prawnym, Wrocław 2003, s. $106-108$. 
daktor naczelny, pozostający poza zarządem ma prawo i obowiązek do określania formy i zawartości pisma, a prezes zarządu rozstrzyga w sprawach dotyczących budżetu i ogólnej strategii pisma. Redaktor naczelny jest całkowicie odpowiedzialny za ukazywanie się i zawartość tytułu. Zarząd określa proporcje pomiędzy materiałami dziennikarskimi a reklamami. Redaktor naczelny decyduje o kształcie stron w ramach ograniczeń wprowadzonych przez zarząd. Prezes przygotowuje i przedstawia kwestie (zwłaszcza edytorskie) dotyczące działalności wydawniczej zarządowi w porozumieniu z redaktorem naczelnym. Redaktor naczelny ma możliwość omówienia tych spraw i zakresu jego odpowiedzialności bezpośrednio z zarządem. W tym modelu, w sytuacji dwóch równorzędnych przywódców, prezes i redaktor naczelny powinni dążyć do wspólnego stanowiska. Gwarancją niezależności dziennikarskiej ma być silna pozycja ekonomiczna tytułu. W praktyce jednak pojawiają się sytuacje zminimalizowania funkcji redaktora naczelnego, a to osłabia niezależność dziennikarzy. Należy wziąć pod uwagę, że pracodawcą dziennikarza jest wydawca. A zatem można powiedzieć, że w modelu tym występuje skomplikowany układ wzajemnych zależności.

$\mathrm{W}$ trzecim modelu redaktor naczelny uzależniony jest od wydawcy. W tym przypadku wydawca pełnię władzy przekazuje przedstawicielowi - dyrektorowi lub prezesowi zarządu, który przejmuje także kompetencje redakcyjne. W związku z tym wpływ redaktora naczelnego na działalność prasową jest pozorny. I dlatego redaktor naczelny uzależniony jest od dobrych stosunków z dyrektorem (prezesem) i jego klientami. Prezes jest silnie związany z wydawca, a wydawca z wpływowymi osobami. Wydawca $\mathrm{z}$ reguły jest zależny od finansowych i politycznych grup nacisku. W rezultacie zarząd zatwierdza budżet pisma, wykorzystuje prawo wydawcy co do wpływu na całokształt funkcjonowania redakcji i ingerencji w politykę, zazwyczaj kadrową pisma. Konflikt pomiędzy redaktorem naczelnym a wydawcą (dyrektorem, prezesem) zarysowuje się w następujących obszarach - zasięg terytorialny pisma (wpływ zarządu; co przyczynia się do powstania nowych stanowisk pracy, biur, kolportażu); tworzenie i likwidacja miejsc pracy (wpływ zarządu); zmiana częstotliwości ukazywania się pisma (wpływ zarządu); zmiana formatu pisma (wpływ zarządu); liczba stron (decyduje redaktor naczelny w porozumieniu z zarządem co do proporcji między zawartością reklam a materiałami dziennikarskimi); profil, układ graficzny, zawartość pisma (redaktor naczelny decyduje biorąc pod uwagę budżet na tę działalność przeznaczony i odpowiada za realizację budżetu). 
Prywatna prasa lokalna mieści się w modelu pierwszym i drugim. Jednak najczęściej posiada pełnię władzy organizacyjnej, ekonomicznej i politycznej. Jest zatem nie tylko redaktorem naczelnym, ale też zarządcą ekonomicznym, a więc wydawcą. Trzeci model będzie właściwy dla pism samorządowych i prasy instytucji kulturalnych oraz wydawców prasy tzw. specjalistycznych społecznych i prywatnych tytułów - pism parafialnych, partyjnych, zakładowych, osiedlowych i typowo komercyjnych np. motoryzacyjnych, reklamowych. Te ostatnie ze względu na wąski zakres tematyczny, pomijający kwestie problemów środowiska lokalnego, tylko w zakresie administracyjnym mogą należeć do prasy lokalnej choć de facto nimi nie są. Problem ten jednak, jak i dodatków do gazet regionalnych o tematyce lokalnej stanowi temat na odrębne opracowanie.

Wolność prasy w demokratycznym państwie to wolność od zewnętrznej ingerencji. Jest ona związana z gwarancjami przed interwencją państwa. Możliwa jest ingerencja na zasadzie cenzury represyjnej, czyli zaskarżaniu do sądu naruszeń obowiązujących przepisów, w szczególności kodeksu karnego, kodeksu cywilnego, ustawy prasowej, ustawy o prawie autorskim i prawach pokrewnych. W praktyce występuje wiele naruszeń wolności prasy, przede wszystkim zewnętrzne naciski elit politycznych. Dla wydawców i redaktorów lokalnych uciążliwe są ograniczenia dotyczące publikowania wiadomości z obrad sesji rady gminy czy powiatu, aktualnych wydarzeń politycznych i danych dotyczących elit władzy. Warto zauważyć, że zdarzały się przypadki utajniania tych obrad, czyli zamykania obrad dla dziennikarzy i preferowanie obecności dziennikarzy danej opcji politycznej. Powszechne jest zatem zjawisko wykorzystywania z różnym skutkiem instrumentów prawnych, ekonomicznych czy politycznych oraz nacisków formalnych, jak i nieformalnych w celu ograniczenia prawa do informacji.

W polu zainteresowania układem zależności: wydawca - redaktor naczelny i dziennikarz najistotniejsza jest cenzura wewnętrzna redakcji. Interesy poszczególnych podmiotów w strukturze mediów są sprzeczne, w momencie gdy wolność prasy dotyczy tylko właścicieli. Gwarancje wolności prasy powinny obejmować wszystkie struktury wewnętrzne, a więc właścicieli, wydawców i dziennikarzy. To ograniczyłoby naciski wywierane na prasę ze strony wewnętrznych grup interesu.

Niezależność i samorządność powinna zostać określona w odpowiednich unormowaniach, osobno dla dziennikarzy, właścicieli i wydawców. Muszą zostać skonkretyzowane prawa i obowiązki tychże grup, dając au- 
tonomię tym grupom i poszerzając obszar ich wolności ${ }^{5}$. Jest to o tyle ważne, gdyż drukowana prasa polska jest w 80\% nakładu w rękach kapitału zagranicznego (przeważnie niemieckiego; badania OBP UJ), co jest niespotykane $\mathrm{w}$ innych krajach europejskich ${ }^{6}$. Rezultatem nieformalnych powiązań i nacisków jest skutecznie działający mechanizm selekcji i interpretacji, co jak wiadomo stanowi istotę cenzury.

Pomimo, iż polskie prawo zabrania cenzury prewencyjnej (art. 54 konstytucji), to jednak nieformalnie istnieje. Cenzorem jest redaktor naczelny i sam dziennikarz dla siebie (autocenzura). Zdarza się często, zwłaszcza w okresie wyborów samorządowych tudzież akcji referendalnych, że dziennikarz ma odmienne zdanie niż redaktor naczelny, lecz aby nie stracić pracy czy stanowiska pisze zgodnie z linią programową wytyczoną przez redaktora naczelnego lub wydawcę. W środowisku lokalnym wbrew pozorom istnieje duża możliwość zweryfikowania poglądów dziennikarzy. W komunikacji bezpośredniej, dziennikarze choć rzadko, to śmiało głoszą swoje poglądy i zainteresowania, zapominając o tym, że żyją i pracują w mikro środowisku. Sytuacje takie odkryte przez redaktora naczelnego czy wydawcę kończą się upomnieniami.

Dziennikarz ma obowiązek realizowania ustalonej w statucie albo regulaminie redakcji ogólnej linii programowej redakcji. W wykonywaniu swoich obowiązków powinien podporządkować się preferencjom ideowym, zawartym w tych dokumentach. Napisanie tekstu niezgodnego z linią programową tytułu, może skończyć się zwolnieniem z pracy, gdyż został naruszony obowiązek pracowniczy ${ }^{7}$. W tym przypadku jednak nie można rozwiązać umowy o pracę bez wypowiedzenia. Natomiast dziennikarze nie związani z redakcją umową o pracę, a działający na rzecz lub z upoważnienia redakcji (np. wykonują zawód w oparciu o umowę zlecenia) także powinni kierować się linią programową redakcji, na rzecz której działają. Oczywiście odejście od linii programowej tego typu dziennikarza nie rodzi rozwiązania stosunku pracy, bo taki nie zaistniał. Ale skutkiem może być nie odnowienie umowy-zlecenia (czy nie odnowienie umowy o dzieło). Realizacja linii programowej może zaprzeczać obowiązkowi „służby społeczeństwu i państwu” (art. 10 ust. 1 p.p.) i być nie-

5 L. Szot, Wolność..., s. 131.

6 B. Michalski, Podstawowe problemy prawa prasowego, Warszawa 1998, s. 15.

7 Ustawa z dnia 26 stycznia 1984 r., Dz. U. 1984, Nr 5, poz. 24, ze zm., art. 10, ust. 2 i 3 . 
zgodna z etyką zawodową i zasadami współżycia społecznego ${ }^{8}$. Jeżeli zaistnieje taki konflikt, to obowiązkiem dziennikarza jest wybór na pierwszym miejscu „służby społeczeństwu i państwu' oraz działania zgodnego z etyką zawodową i zasadami współżycia.

W praktyce, nieliczne redakcje posiadają statuty (regulamin) redakcyjne, które określają linię programową redakcji. W przypadkach braku regulaminu, redaktorzy naczelni, a pośrednio wydawca nakreślają linię programową na bieżąco w sposób ustny, a taka forma przecież nie rodzi prawnego obowiązku realizowania takowej linii ${ }^{9}$. Pomimo tego ustna forma linii programowej staje się podstawą do autocenzury. Od decyzji redaktora naczelnego dotyczącej naruszenia obowiązku pracowniczego można odwołać się do kolegium redakcyjnego, o ile takie ciało istnieje. Jednak jest to zespół, w którego skład wchodzi redaktor naczelny i jego zastępcy oraz kierownicy działów. Tutaj w grę wchodzą też, oprócz powiązań zawodowych, silne związki personalne. Dziennikarz dokonując wewnętrznej selekcji materiałów wie doskonale kogo ma popierać i jakie inicjatywy, a zatem zna preferencje polityczne redakcji. Negatywnym tego skutkiem jest milczenie medialne w pewnych frapujących, najczęściej politycznych kwestiach. Przestrzeganie linii programowej ogranicza więc wolność dziennikarzy. Ale zapewnia pismu jednolity charakter i często wychodzi naprzeciw oczekiwaniom odbiorców.

Na rynku prasy lokalnej tak jak w mediach ogólnopolskich czy regionalnych dostrzegalna jest coraz częstsza rotacja kadr dziennikarskich. Gazety lokalne ,przechwytują” znanych lokalnych dziennikarzy, ci też często mając za sobą jakąś grupę nacisku tworzą od podstaw własne pisma. Zatem wewnętrzna cenzura jest ważna dla tych dziennikarzy, którzy posiadają wysokie gaże i wiedzą o tym, że nigdzie większych nie otrzymają bądź dla tych, którzy chcą utrzymać swój stosunek pracy.

Trzeba jednak podkreślić, że zjawisko cenzury wewnętrznej powoduje to, że prasa traci swoją niezależność, a ostatecznie i wiarygodność. Należy też podkreślić, że za cenzurę wewnątrzredakcyjną nie uważa się m.in. niepublikowania materiałów niezgodnych $\mathrm{z}$ linią programową pisma, eliminowania treści naruszających prawa osób trzecich lub mogących być podstawą do odpowiedzialności prawnej (redakcji, dziennikarza, wydawcy).

Sytuację wydawców, redaktorów naczelnych i dziennikarzy powinny regulować statuty. Powinny szczególnie dokładnie określać ich zadania

8 J. Sobczak, Prawo prasowe. Podręcznik akademicki, Warszawa 2000, s. 207.

9 J. Sobczak, Prawo prasowe..., s. 206. 
i rozdział obowiązków. Statuty są bardzo rzadko tworzone w redakcjach lokalnych. Trudno jest egzekwować powstawanie statutów, skoro nie można wyegzekwować rejestracji prasy lokalnej, podstawy prawnej do jej funkcjonowania. Tę dramatyczną sytuację badacze prasy lokalnej podkreślają wielokrotnie. A przykładem może być chociażby obszar byłego województwa leszczyńskiego, będący zagłębiem prasowych inicjatyw lokalnych. W latach 1989-2003 na 85 pism, aż ponad połowa z nich nie była zarejestrowana $^{10}$. Zjawisko braku rejestracji dotyczyło większości tytułów ukazujących się w latach 1989-1994. Redaktorzy zaniechanie takie tłumaczą zbyt dużym obciążeniem redakcji ze strony ustawodawcy, przejawiającym się obowiązkiem wysyłania egzemplarzy prasy do bibliotek, placówek naukowych, w sytuacji gdy prasa lokalna jest niskonakładowa i nierentowna. Ten proceder nierejestrowania czasopism lokalnych jest typowy także dla instytucji samorządowych, które to przecież z założenia jako wzór dla obywateli - powinny działać zgodnie z prawem. Warto nadmienić również, że sądowe księgi rejestrowe nie są dobrym źródłem informacji o ukazywaniu się prasy, z uwagi na częste występujące w nich braki zapisu o likwidacji czy zawieszeniu pisma. Zatem ograniczenia niezależności w układzie redaktor naczelny - dziennikarz - wydawca mają miejsce w pismach lokalnych, które w większości de facto nie istnieją w państwie prawa.

\section{Summary}

Financial standing of a newspaper is decisive for journalist freedom and independence. It may be observed in the journalistic reality of local newspapers, particularly of those privately owned, that financial matters usually predominate over journalistic ethics. Such practice overshadows the apparently noncommercial nature of the press that is emphasized by the editorial office. Most titles make an overt reference to their independence and stimulating role. The latter is most likely to refer to the influence the press exerts on the public awareness, which contradicts the commercial purposes. In contrast to private newspapers, the titles owned or subsidized by local governments are not profit-oriented. The journalists in such newspapers frequently work pro publico bono and are not remunerated for their work. It is essential for such editorial teams that the society approves the institutions their newspapers represent.

10 Opracowanie własne. 